\title{
FLUORIDE REMOVAL FROM GROUNDWATER BY TECHNOLOGICAL PROCESS OPTIMIZATION
}

\author{
OPTYMALIZACJA PROCESÓW TECHNOLOGICZNYCH \\ USUWANIA FLUORU Z WÓD PODZIEMNYCH
}

\begin{abstract}
Fluoride removal from aqueous solutions was studied using nanofiltration and sorption techniques which have always been best key ways to deal with water contaminated by fluoride. In this presented work, we were firstly interested on fluoridated rejected water overcoming the drawback of RO membrane process of groundwater treatment plant in Baltic region (Kretinga, Lithuania). Opoka sorbent has shown effective results of fluoride sorption with efficiency higher than $77 \%$. In order to understand the sorption phenomenon and to validate the results obtained, we have applied experimental data on Freundlich and Langmuir isotherms which allow us to determine isotherms parameters $\left(K_{F} ; 1 / n\right.$ and $\left.K_{L} ; q_{\max }\right)$ and to confirm the experiment. Because of the unacceptable tariff of drinking water treated by RO, defluoridation with nanofiltration method is proposed in this study as a solution which can replace reverse osmosis technique. For that, tests of nanofiltration for fluoride removal were carried out at laboratory scale by using nanofiltration flat sheet membranes (NF270 and NF90).
\end{abstract}

Keywords: fluoride, isotherm, nanofiltration, opoka, rejected water, sorption

\section{Introduction}

The contamination of groundwater via fluorine is a class of natural pollution which is in general depends on the occurrence of fluoride-bearing minerals [1]. Fluoride can be present in groundwater naturally when conditions favor the dissolution of some fluoride minerals, such as, sellaite $\left(\mathrm{MgF}_{2}\right)$, fluorspar $\left(\mathrm{CaF}_{2}\right)$, cryolite $\left(\mathrm{Na}_{3} \mathrm{AlF}_{6}\right)$ and fluorapatite $\left[3 \mathrm{Ca}_{3}\left(\mathrm{PO}_{4}\right)_{2} \mathrm{Ca}\left(\mathrm{F}, \mathrm{Cl}_{2}\right)\right][2]$.

Groundwaters contaminated by high concentrations of fluoride are found in many countries around the world, notably in Africa, South Asia, China and USA [3-6]. Most important concentrations of fluoride in groundwater were found in India and the Rift Valley's groundwater [7, 8]. In the western part of Lithuania the concentration of natural

\footnotetext{
${ }^{1}$ Department of Environment Protection and Water Management, Vilnius Gediminas Technical University, Sauletekio ave. 11, Vilnius, LT-10223, Lithuania, phone +37061653746

${ }^{2}$ Department of Building Materials and Fire Safety, Vilnius Gediminas Technical University, Sauletekio ave. 11, Vilnius, LT-10223, Lithuania, phone +37063189130, email: ramune.zurauskiene@ vgtu.lt

${ }^{3}$ Laboratory of Applied Chemistry, Faculty of Science and Technology, Sidi Mohammed Ben Abdellah University, P.O. Box 2202, Fez, Morocco, email: boussouga.youssef@ gmail.com

*Corresponding author: marina.valentukeviciene@vgtu.lt
} 
fluoride in water is high and varies from 1.5 to $5 \mathrm{mg} / \mathrm{dm}^{3}$ [9]. In the region of Doukkala (Centre of Morocco) groundwater contains many excessive ions, especially fluoride with $3.25 \mathrm{mg} / \mathrm{dm}^{3}$ concentration [10]. A detailed description on the highest concentrations of fluoride reported in groundwater of some regions around the world based on literature $[4,5]$ is given in Table 1.

Table 1

Highest fluoride levels reported in different countries

\begin{tabular}{|c|c|c|c|c|}
\hline Country & Location & Water source & {$\left[\mathbf{F}^{-}\right]$range $\left[\mathbf{m g} / \mathbf{d m}^{3}\right]$} & References \\
\hline Ghana & $\begin{array}{c}\text { Nathenje and } \\
\text { Lilongwe }\end{array}$ & $\begin{array}{c}\text { Shallow and deep } \\
\text { groundwater }\end{array}$ & $0.5-7.02$ & {$[11]$} \\
\hline India & Gujarat & Groundwater & $0.1-40$ & {$[12]$} \\
\hline China & $\begin{array}{c}\text { Zhuiger Basin, } \\
\text { Kuitun area }\end{array}$ & Groundwater & $0-21.5$ & {$[13]$} \\
\hline USA & $\begin{array}{c}\text { Yellowstone National } \\
\text { Park }\end{array}$ & Groundwater & $25-50$ & {$[14]$} \\
\hline Ethiopian & Rift Valley & - & $0.21-22.5$ & {$[15]$} \\
\hline
\end{tabular}

Fluorine is the world's 13th most abundant element and has the highest electronegativity. About $50 \%$ of ingested fluoride is absorbed by bones and teeth while the rest is excreted with urine. At an optimal level, fluoride can have some positive impacts on human health by interacting with hydroxyapatite of teeth to form fluoroapatite, which is less susceptible to erosion by acid-producing oral bacteria [16]. Fluorine can have also another beneficial effect of increasing the size of apatite crystals in bones and reducing their solubility, thereafter stabilizing the skeletal system [17]. According to WHO (the World Health Organization) recommendations, the optimal fluoride level in drinking water is $1.5 \mathrm{mg} / \mathrm{dm}^{3}$ [18]. In some cases, when people consume water with very high levels of fluoride, their health can be affected negatively by inducing fluorosis (dental fluorosis and skeletal fluorosis); which is a chronic metabolic disease caused by ingestion or inhalation of large amounts of fluoride [16].

The main objective of defluoridation is to remove the excess of fluoride from aqueous solutions, and to bring it down to acceptable standards [19-21]. Sorption techniques and membrane separation processes (nanofiltration, reverse osmosis and electro-dialysis) are the most common methods used to deal with this problem; there are other processes also used for water defluoridation such as, coagulation-precipitation and ion exchange. Each technique has its advantages and limitations, while the performance and the cost present the biggest challenge. All the above approaches, which were used by many authors, are represented in Table 2 with their application on defluoridation and their performance.

Coagulation-precipitation methods always are based on chemical agents, the ion exchange requires a longer period of reaction. For this reason, methods of sorption and membrane separation are the most commonly used during water treatment from exhaustive elements. The combination of these two methods can lead us to an optimal treatment, as was reported by [22].

Concentrate or rejected water from RO membrane represents one of the drawbacks of the membrane process, which is that the treatment of the concentrate is necessary to not affect the environment. Defluoridation of different kinds of rejected water has been studied by many authors by using different methods of treatment; one of them being membrane treatment of wastewater from a fertilizer factory with retention higher than $96 \%$ for 
$17.7 \mathrm{mg} / \mathrm{dm}^{3}$ of fluoride level [23]. The treatment was also investigated by precipitation techniques; using $\mathrm{Ca}(\mathrm{OH})_{2}$ and $\mathrm{CaCl}_{2}$ for the treatment of fluoride concentrate from membrane unit with an efficiency higher than $93 \%$ for $150 \mathrm{mg} / \mathrm{dm}^{3}$ of initial fluoride concentration [24], and by $\mathrm{CaCO}_{3}$ with $93 \%$ of efficiency for $109 \mathrm{mg} / \mathrm{dm}^{3}$ of fluoride concentration [25].

According to the research results provided by [26], the fluoride adsorption capacity was $25.8 \mathrm{mg} \mathrm{F}^{-} / \mathrm{g}$ of aluminium based adsorbent, which is high compared to commercially available activated alumina (1.8 to $1.9 \mathrm{mg} / \mathrm{g}$ ). Kinetic studies showed that the rate of adsorption in continuous studies was in the range of $6.12 \cdot 10^{-3}$ to $39.3 \cdot 10^{-3} \mathrm{dm}^{3} /(\mathrm{mg} \cdot \mathrm{h})$ under different operating conditions.

The opoka stone, which is a natural sorbent rich in calcium carbonate $\left(\mathrm{CaCO}_{3}\right)$, was selected in order to reduce the treatment cost, to reuse the rejected water and to meet the standards of drinking water. Opoka stone sources were used in Lithuania and Poland for the last decade for drinking water and wastewater treatment due to of the low cost and its well-investigated properties.

Initial concentrations of fluoride $\left(\left[\mathrm{F}^{-}\right]_{\mathrm{Feed}}\right)$ are summarized in Table 2 for different processes of membrane separation and fluoride adsorption.

Table 2

Materials and methods of defluoridation

\begin{tabular}{|c|c|c|c|c|c|}
\hline Process & Material & Country & {$\left[\mathbf{F}^{-}\right]_{\text {Feed }}\left[\mathbf{m g} / \mathbf{d m}^{\mathbf{3}}\right]$} & Efficiency [\%] & References \\
\hline \multirow{4}{*}{$\begin{array}{c}\text { Membrane } \\
\text { separation }\end{array}$} & NF & Senegal & 3.76 & 88 & {$[27]$} \\
\cline { 2 - 6 } & NF & India & 20 & 98 & {$[28]$} \\
\cline { 2 - 6 } & RO & Tanzania & 47.6 & 98.7 & {$[29]$} \\
\cline { 2 - 6 } & ED & Morocco & 2.32 & 67.7 & {$[30]$} \\
\cline { 2 - 6 } Adsorption & Bone charcoal & Thailand & 3.5 & 90 & {$[31]$} \\
\cline { 2 - 6 } & Glays & Algeria & 2.7 & $37-73$ & {$[32]$} \\
\cline { 2 - 6 } & $\begin{array}{c}\text { Granular ferric } \\
\text { hydroxide }\end{array}$ & Nigeria & $2.6-29.6$ & 65 & {$[34]$} \\
\hline
\end{tabular}

We were investigating low cost sorbents, due to all inhabitants complains about the high tariff of drinking water in the town which is due to the huge energy used by the reverse osmosis process and approximately $30 \%$ water losses caused by rejected concentrated fluids. We discuss the innovation of these natural sorbents and the insight gained from their advances that can help develop cost-effective reusable technologies for practical use. This work discusses the innovation of these natural sorbents and the insight gained from their advances that can help develop cost-effective reusable technologies for practical use. Due to the mentioned above reason of unacceptable tariff for drinking water treated by RO, the co-authors of this article carried out the research of fluoride removal from aqueous solutions with two nanofiltration membranes (NF270 and NF90).

Both methods were presented with related efficiency and cost related analysis to the water company responsible for drinking water supply to all inhabitants of Kretinga town (Lithuania). Coauthors of this article propose that this article may be useful for engineering practice. 


\section{Materials and methods}

\section{The studies of rejected water}

The rejected water studied in this present work comes from the groundwater treatment plant situated in Kretinga, Lithuania. The groundwater in this region is characterized by a high rate of iron and fluoride as shown in Table 3. In general, the treatment process of the groundwater in this station firstly involves the removal of iron(II) by transforming it to iron(III) in the form of hydroxide $\mathrm{Fe}(\mathrm{OH})_{3}$ via a bacteriological treatment with aeration. The iron hydroxide III then is recovered as backwash residue thanks to the sand filters. After that, defluoridation is carried out by a membrane process by using reverse osmosis.

Table 3

Physico-chemical characteristics of groundwater in Tarvydai region (Kretinga-Lithuania)

\begin{tabular}{|c|c|c|c|c|c|}
\hline Analyze & Unit & $\begin{array}{c}\text { Lithuanian hygiene } \\
\text { norms [35] }\end{array}$ & $\begin{array}{c}\text { Maximum value } \\
\text { detected }\end{array}$ & $\begin{array}{c}\text { Minimum value } \\
\text { detected }\end{array}$ & Average value \\
\hline $\mathrm{pH}$ & {$[-]$} & $6.5-9.5$ & 8.0 & 7.6 & 7.7 \\
\hline Conductivity & {$\left[\mu \mathrm{s} / \mathrm{cm}\right.$ at $\left.25^{\circ} \mathrm{C}\right]$} & 2500 & 735 & 650 & 690 \\
\hline $\mathrm{Fe}$ & {$\left[\mu \mathrm{g} / \mathrm{dm}^{3}\right]$} & 200 & 1100 & 450 & 775 \\
\hline $\mathrm{Mn}$ & {$\left[\mu \mathrm{g} / \mathrm{dm}^{3}\right]$} & 50 & 10 & 10 & 10 \\
\hline $\mathrm{SO}_{4}{ }^{2-}$ & {$\left[\mathrm{mg} / \mathrm{dm}^{3}\right]$} & 250 & - & - & 134 \\
\hline $\mathrm{Cl}^{-}$ & {$\left[\mathrm{mg} / \mathrm{dm}^{3}\right]$} & 50 & - & - & 17 \\
\hline $\mathrm{F}^{-}$ & {$\left[\mathrm{mg} / \mathrm{dm}^{3}\right]$} & 1.5 & 2.7 & 1.6 & 2.1 \\
\hline $\mathrm{NO}_{3}{ }^{-}$ & {$\left[\mathrm{mg} / \mathrm{dm}^{3}\right]$} & 50.00 & - & - & 0.01 \\
\hline $\mathrm{NO}_{2}{ }^{-}$ & {$\left[\mathrm{mg} / \mathrm{dm}^{3}\right]$} & 0.10 & - & - & 0.01 \\
\hline $\mathrm{NH}_{4}{ }^{+}$ & {$\left[\mathrm{mg} / \mathrm{dm}^{3}\right]$} & 0.50 & 0.36 & 0.01 & 0.21 \\
\hline
\end{tabular}

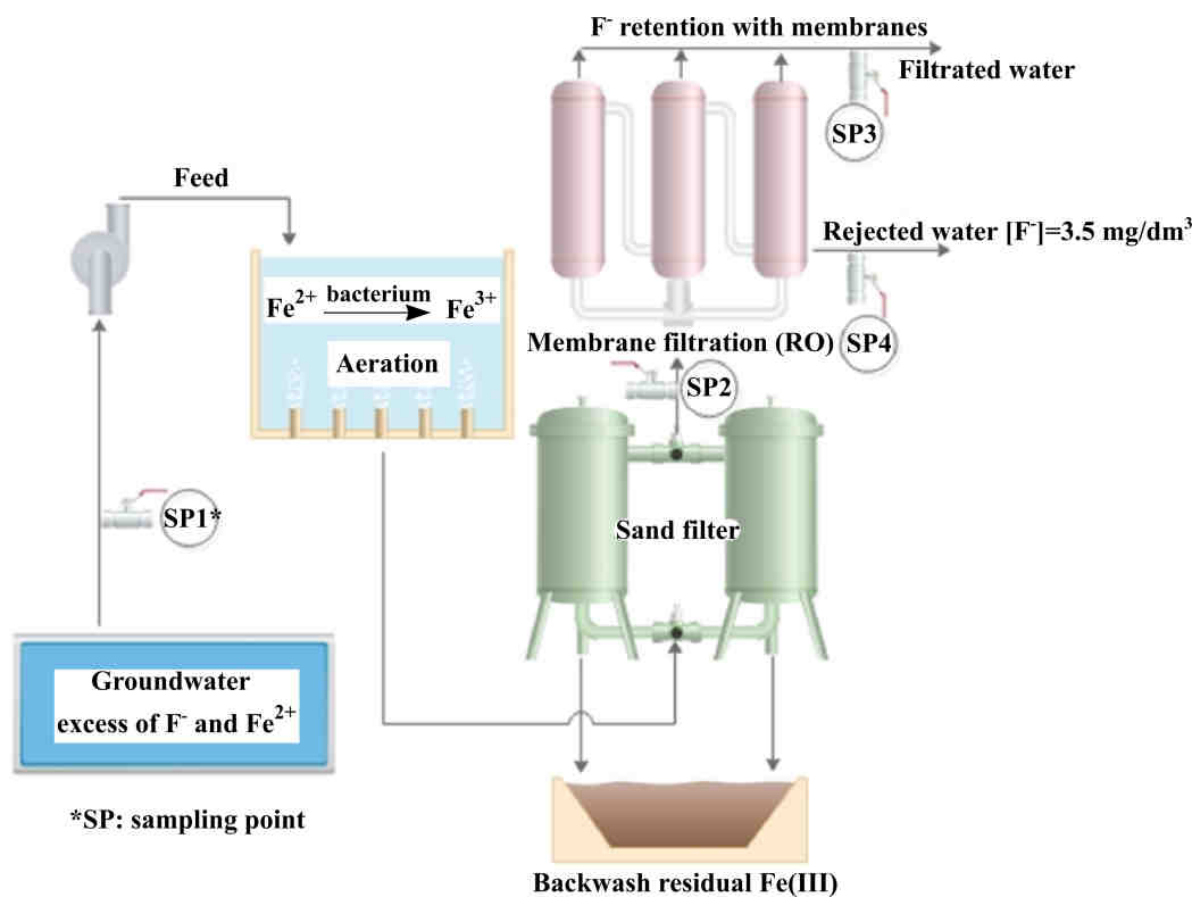

Fig. 1. Schematic diagram of groundwater treatment plant (Kretinga-Lithuania) 
A problem arises in this process since the rejected water via membrane process has an average concentration of $3.5 \mathrm{mg} / \mathrm{dm}^{3}$ and treatment of the concentrate is necessary before being released to the sewer. A schematic representation of the groundwater treatment plant is shown in Figure 1.

\section{The sampling and characterization of sorbents}

The opoka stone, which is a silica-calcite sedimentary rock, occurs in Poland and Lithuania and has properties that qualify it for water purification [36]. Opoka sorbent has been studied by many authors, for water treatment from phosphorus [37, 38], sorption and decomposition of coolants [39] and as carbon dioxide sorbent [40].

The granulometric composition was determined by employing standard methods described in LST EN 933-2:2000 [41], and investigation of microstructure was carried out by employing SEM "Quanta" 250 with secondary electron detector.

Opoka sorbent samples has been analyzed before and after treatment for each experiment by using NITON XLp XRF Analyzer which is a single unit, hand held, and high performance portable X-ray fluorescence (XRF) elemental analyzer provided from Thermo Fisher Scientific. This method was useful to characterize our sorbent and thereafter to define the responsible elements of the sorption phenomenon. Prior to analysis, the material should be dry and well homogenized. Ideally, the entire sample should be dried for approximately 2 hours at $150{ }^{\circ} \mathrm{C}$, until the sample reaches a constant weight. Next, the sample should be milled and sifted to a fine powder until the entire fraction is able to pass through a $125 \mu \mathrm{m}$ mesh. Then, at least five grams of the prepared sample should be placed in an XRF Sample Cup. After wards, the sample could be ready for testing with a $95 \%$ confidence interval.

\section{Sorption experiment}

A sorption experiment was carried out on membrane process rejected water which was contaminated by fluoride and opoka stone as sorbent. Different quantities of opoka sorbent $(5,10,15$ and $20 \mathrm{~g})$ were mixed with $1 \mathrm{dm}^{3}$ of solution by using Jar-test as a mixer-test for $30 \mathrm{~min}$ with an average rotation, and then each solution was left to stand for $30 \mathrm{~min}$. During the experiment, the fluoride concentration was analyzed by a spectrophotometer (Spectroquant Nova $60 \mathrm{MERCK}$ ). The conductivity and $\mathrm{pH}$ were also controlled during the experiment.

\section{Equilibrium isotherm analysis}

Freundlich isotherm. In order to define the efficiency and the equilibrium sorption of opoka sorbent, we were intrigued to apply the previous results on the Freundlich Isotherm, which was originally developed as an empirical model, which is written as follows [33, 42]:

$$
\begin{gathered}
q_{e}=K_{F} \cdot C_{e}^{1 / n} \\
\log q_{e}=\frac{1}{n} \log C_{e}+\log K_{F}
\end{gathered}
$$

where $C_{e}$ is the solute concentration in the solution at equilibrium $\left[\mathrm{mg} / \mathrm{dm}^{3}\right], q_{e}$ the solute mass adsorbed per unit sorbent mass at equilibrium $[\mathrm{mg} / \mathrm{g}], K_{F}$ is the constant of the Freundlich isotherm $\left[\left(\mathrm{dm}^{3}\right)^{1 / n} \mathrm{mg}^{(1-1 / n)} / \mathrm{g}\right]$, and $1 / n$ is the Freundlich exponent. 
Langmuir isotherm. The Langmuir isotherm, which assumes monolayer sorption onto a sorbent surface, can be expressed by the following linear equation [33, 41]:

$$
\frac{1}{q_{e}}=\left(\frac{1}{K_{L} \cdot q_{\max }}\right) \cdot \frac{1}{C_{e}}+\frac{1}{q_{\max }}
$$

where $K_{L}\left[\mathrm{dm}^{3} / \mathrm{mg}\right]$ is the constant of Langmuir isotherm and $q_{\max }[\mathrm{mg} / \mathrm{g}]$ relates to the maximum sorption capacity.

To decide if the sorption process is beneficial or inappropriate for the Langmuir type sorption process, the isotherm can be described by a term $R_{L}$, a dimensionless constant, the separation factor which is expressed by the following equation:

$$
R_{L}=\frac{1}{\left(1+K_{L} C_{0}\right)}
$$

where $C_{0}$ is the highest, initial solute concentration in the liquid phase. The $R_{L}$ value implies that sorption is unfavorable $\left(R_{L}>1\right)$, linear $\left(R_{L}=1\right)$, favorable $\left(0<R_{L}<1\right)$, or irreversible $\left(R_{L}=0\right)$.

\section{Nanofiltration experiment}

Tests of filtration have been done at laboratory scale with a planar cross flow module provided by the company Osmonics for flat sheet NF membranes with an area of $138 \mathrm{~cm}^{2}$. The module also has a hydraulic clamping system used to work up to $6.9 \mathrm{MPa}$ of pressure. The unit also has a pump HP (Wanner, USA) which features a feeding circulation speed regulator. The total volume of the system is $5 \mathrm{dm}^{3}$. A schematic representation of the equipment is illustrated in Figure 2.

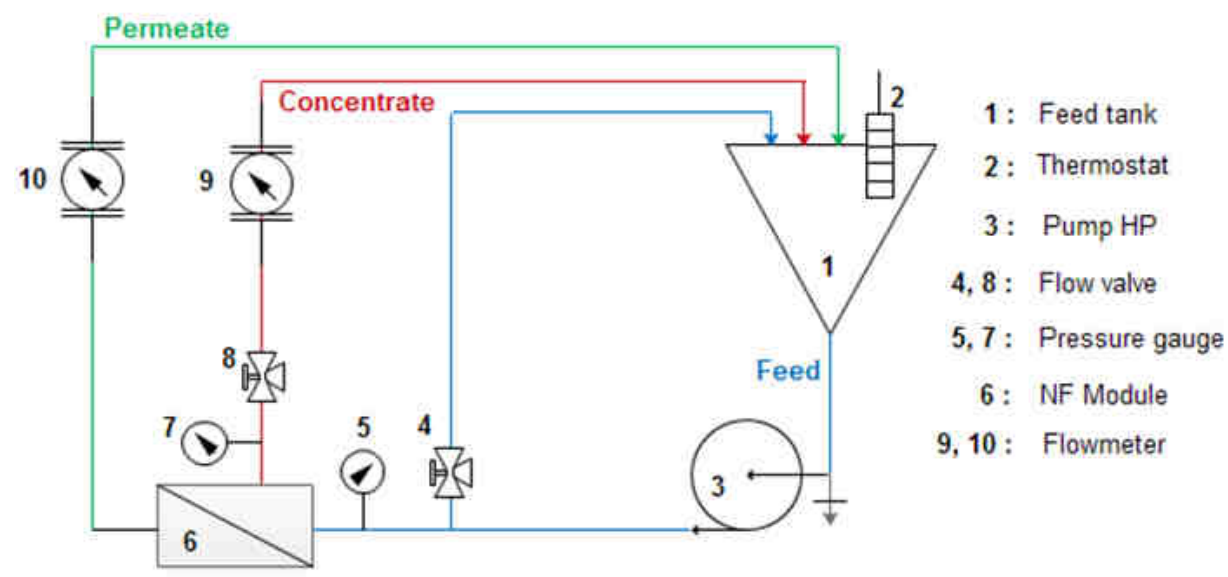

Fig. 2. Schematic representation of nanofiltration assembly (LCA, FST-USMBA, Fez-Morocco)

The study was conducted on Polyamide Thin-Film Composite nanofiltration membranes (NF270 and NF90), provided by the company FilmtecDow. These membranes have a maximum temperature of $45^{\circ} \mathrm{C}$, maximum pressure of $4.1 \mathrm{MPa}$ and operating $\mathrm{pH}$ range from 3 to 10 . 
Operational parameters. The performance of membrane retention can be evaluated by the observed rejection rate $R_{o b s}$ which can be written with the following equation:

$$
R_{o b s}=\left(1-\frac{C_{p}}{C_{0}}\right) \cdot 100
$$

where $C_{0}$ and $C_{p}$ define the concentration of fluoride in the feed tank and in permeate respectively.

Due to being based on Darcy's law, the hydraulic permeability with pure water of a membrane represents the permeate flux as a function of the applied pressure:

$$
J_{v}=L_{p} \Delta P
$$

where $J_{v}\left[\mathrm{dm}^{3} \cdot \mathrm{h}^{-1} \cdot \mathrm{m}^{-2}\right]$ is the solvent flux; $\Delta P[\mathrm{~Pa}]$ defines the transmembrane pressure; $L_{p}\left[\mathrm{dm}^{3} \cdot \mathrm{h}^{-1} \cdot \mathrm{m}^{-2} \cdot \mathrm{Pa}^{-1}\right]$ is the hydraulic permeability with pure water.

The conversion rate $Y$ was fixed at $15 \%$ in the system during filtration process due to the following equation:

$$
Y=\left(\frac{Q_{p}}{Q_{0}}\right) \cdot 100
$$

where $Q_{0}$ and $Q_{p}$ define the feed flow and the permeate flow respectively.

$N F$ surface characterization [42]. The surface imagery was examined with the scanning electron microscope (SEM) JSM-7600F (JEOL). The scanning of NF membranes was performed at accelerating voltage: 4 and $10 \mathrm{kV}$, the mode of secondary electrons was used in image formation. The examined samples were covered with a layer of electricity conducting material, using device QUORUM Q150R ES.

\section{Results}

\section{Granulometric composition and microstructure of opoka sorbent}

Granulometric composition of opoka sorbent was determined as shown in Figure 3. The opoka stone particles granulometric composition has high amount of smaller particles which size is between 0.07 and $0.14 \mathrm{~mm}$.

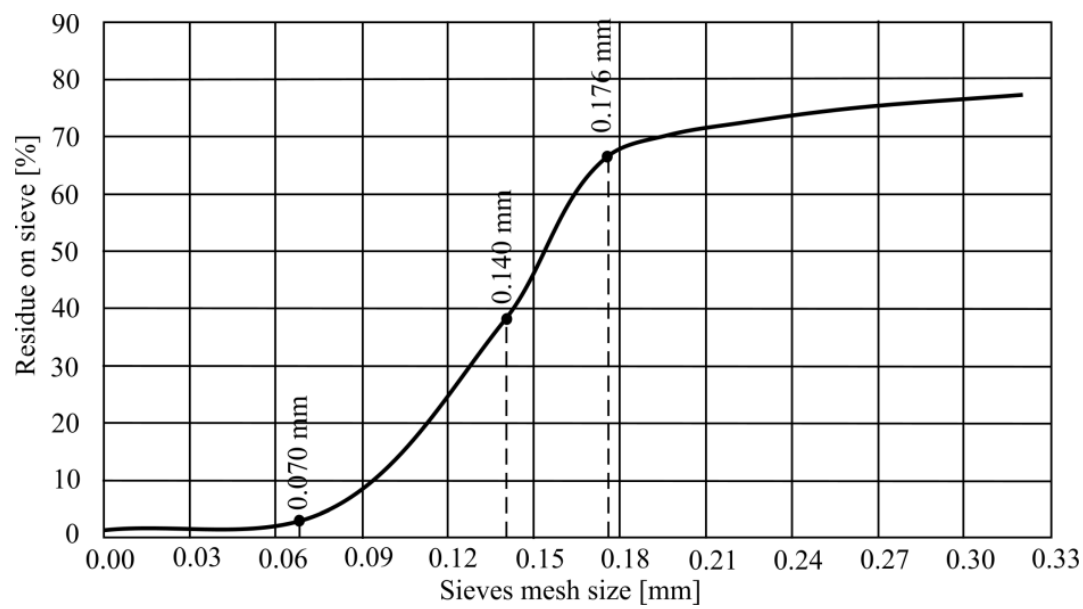

Fig. 3. Granulometric composition of the opoka sorbent 
SEM instrument provided enlarged pictures of sorbent surface and some composition of compounds (i.e. see Figure 4). The absorbent particle size was smaller than $0.63 \mathrm{~mm}$. It can be seen in Figure 4 that every absorbent particle is covered in small crystals, mainly flat form crystals, which size is about 1 micrometer. Small flat form crystals on particle surface enlarge every particle's surface area. Results in [weight \%] of all elements analyzed for spectrum 1 and spectrum 2 selected in Figure 4 are shown in Table 4.

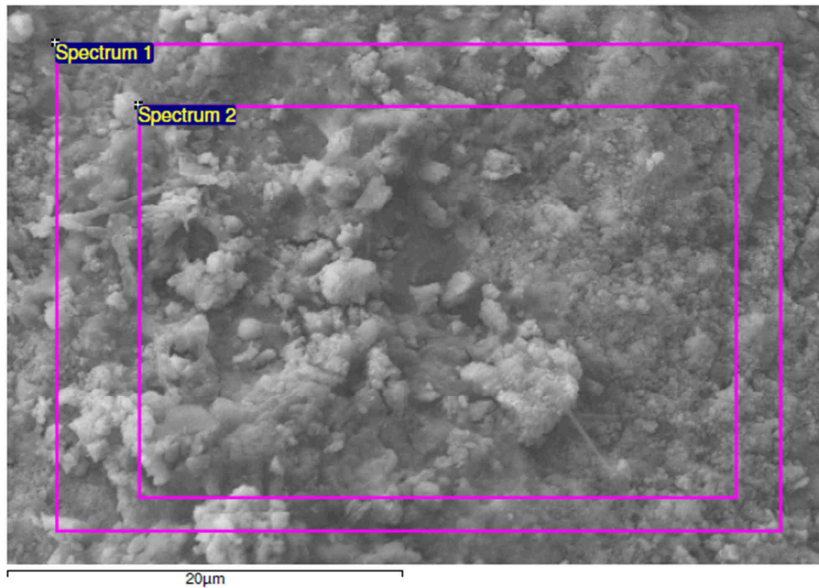

Fig. 4. SEM picture with enlarged opoka sorbent surface

Results in [weight \%] according to processing option when all elements analyzed

\begin{tabular}{|c|c|c|c|c|c|}
\hline \multirow{2}{*}{ Mark } & \multicolumn{5}{|c|}{ Element [\%] } \\
\cline { 2 - 6 } & $\mathbf{O}$ & Al & Si & K & Ca \\
\hline Spectrum 1 & 57 & 4.00 & 29.0 & 1.28 & 8.7 \\
\hline Spectrum 2 & 56 & 4.04 & 27.3 & 1.53 & 10.8 \\
\hline Mean & 57 & 4.02 & 28.1 & 1.40 & 9.8 \\
\hline Std. deviation & 0.48 & 0.03 & 1.2 & 0.18 & 1.5 \\
\hline
\end{tabular}

\section{Sorption efficiency}

Table 5 presents some physicochemical characteristics of the membrane process rejected water studied before and after treatment with opoka sorbent. According to the values of fluoride concentration, fluoride sorption was done for all experiments.

Physicochemical characteristics of rejected water before and after treatment with opoka sorbent

\begin{tabular}{|c|c|c|c|c|c|c|}
\hline \multirow{2}{*}{ Parameter } & \multirow{2}{*}{$\begin{array}{c}\text { Before } \\
\text { treatment }\end{array}$} & \multicolumn{4}{|c|}{ After treatment with opoka sorbent } & \multirow{2}{*}{ [35] } \\
\hline & & $5 \mathrm{~g}$ & $10 \mathrm{~g}$ & $15 \mathrm{~g}$ & $20 \mathrm{~g}$ & \\
\hline$\chi_{0}[\mu \mathrm{s} / \mathrm{cm}]$ & 1891 & 1936 & 1936 & 1939 & 1940 & \multirow{2}{*}{$<2500$} \\
\hline$\chi_{e q}[\mu \mathrm{s} / \mathrm{cm}]$ & - & 1930 & 1930 & 1925 & 1855 & \\
\hline$\left[\mathrm{F}^{-}\right]\left[\mathrm{mg} / \mathrm{dm}^{3}\right]$ & 3.5 & 2.6 & 1.7 & 1.2 & 0.8 & $<1.5$ \\
\hline $\mathrm{pH}$ & 7.7 & 7.9 & 8.1 & 8.2 & 8.3 & \multirow{2}{*}{$6.5-9.5$} \\
\hline $\mathrm{pH}_{\mathrm{eq}}$ & - & 8.2 & 8.4 & 8.4 & 8.4 & \\
\hline Efficiency [\%] & - & 25.7 & 51.4 & 65.7 & 77.1 & - \\
\hline
\end{tabular}


At equilibrium and from $15 \mathrm{~g}$ of opoka sorbent, all parameters of $\mathrm{pH}$, conductivity and fluoride concentration meet Lithuanian standards of drinking water, which means that the sorption process can be combined with the membrane process to produce drinking water with a higher production rate.

\section{X-ray characterization}

In order to characterize opoka sorbent, we have analyzed them after drying with the X-ray fluorescence (XRF) method. The elemental profiles of opoka sorbent obtained are shown in Table 6.

Table 6

Characteristics of opoka sorbent before and after defluoridation of membrane process rejected water

\begin{tabular}{|c|c|c|c|c|c|}
\hline \multirow{3}{*}{ Element } & \multirow{2}{*}{$\begin{array}{l}\text { Opoka before } \\
\text { defluoridation }\end{array}$} & \multicolumn{4}{|c|}{ Opoka after defluoridation } \\
\hline & & $5 \mathrm{~g}$ & $10 \mathrm{~g}$ & $15 \mathrm{~g}$ & $20 \mathrm{~g}$ \\
\hline & \multicolumn{5}{|c|}{ [ppm] } \\
\hline $\mathrm{Cd}$ & $17.0 \pm 6.5$ & $24.1 \pm 7.2$ & $20.9 \pm 6.9$ & $18.9 \pm 6.3$ & - \\
\hline $\mathrm{Zn}$ & $46.4 \pm 8.4$ & $33.8 \pm 6.4$ & $64.1 \pm 7.7$ & $41.3 \pm 7.0$ & $37.8 \pm 7.0$ \\
\hline $\mathrm{Ba}$ & $290 \pm 17$ & $182 \pm 15$ & $151 \pm 17$ & $288 \pm 17$ & $248 \pm 17$ \\
\hline $\mathrm{Sn}$ & $42.1 \pm 9.9$ & $31.9 \pm 8.7$ & $24 \pm 11$ & $46.5 \pm 8.7$ & $32.6 \pm 9.1$ \\
\hline $\mathrm{Zr}$ & $67 \pm 14$ & $64 \pm 13$ & $78 \pm 14$ & $58 \pm 14$ & $52 \pm 12$ \\
\hline $\mathrm{Sr}$ & $834.3 \pm 5.0$ & $885.7 \pm 4.2$ & $891.3 \pm 5.1$ & $895.7 \pm 5.0$ & $840.4 \pm 5.2$ \\
\hline $\mathrm{Rb}$ & $21.6 \pm 3.6$ & $19.6 \pm 4.1$ & $21.6 \pm 4.7$ & $21.2 \pm 3.9$ & $19.9 \pm 4.3$ \\
\hline $\mathrm{Fe}$ & $6264 \pm 162$ & $6125 \pm 163$ & $6218 \pm 197$ & $5915 \pm 258$ & $6000 \pm 274$ \\
\hline $\mathrm{Ti}$ & $429 \pm 82$ & $457 \pm 83$ & $486 \pm 67$ & $393 \pm 74$ & $382 \pm 57$ \\
\hline $\mathrm{Ca}$ & $210438 \pm 477$ & $200235 \pm 218$ & $203163 \pm 512$ & $207600 \pm 418$ & $204601 \pm 237$ \\
\hline $\mathrm{K}$ & $4879 \pm 479$ & $4791 \pm 461$ & $5053 \pm 458$ & $4486 \pm 491$ & $4756 \pm 430$ \\
\hline $\mathrm{S}$ & $1421 \pm 740$ & $1435 \pm 576$ & $1341 \pm 552$ & $1264 \pm 677$ & $1013 \pm 589$ \\
\hline
\end{tabular}

The results of XRF showed that the opoka sorbent is a material rich with calcium. The majority of the other elements detected in the sample were present in minor or trace quantities. After combining and analyzing the results in Tables 5 and 6, it can be noted that fluoride has strongly reacted with the calcium-containing compound from opoka sorbent, generally as $\mathrm{CaCO}_{3}$ [36], since the amount of calcium in opoka has decreased compared to other elements.

\section{Equilibrium isotherm parameters}

In any sorption experiment, $C_{e}$ can be measured and $\mathrm{q}_{\mathrm{e}}$ can be calculated for series of different conditions as shown in Table 7. Then $\log q_{e}$ can be plotted as function of $\log C_{e}$ for Freundlich isotherm (i.e. see Figure 5a) or $1 / q_{e}$ as function of $1 / C_{e}$ for Langmuir isotherm as shown in Figure 5b.

The necessary parameters for equilibrium Isotherm application

\begin{tabular}{|c|c|c|c|c|}
\hline $\boldsymbol{C}_{\mathbf{0}}\left[\mathbf{m g} / \mathbf{d m}^{\mathbf{3}}\right]$ & $\boldsymbol{M}[\mathbf{g}]$ & $\boldsymbol{C}_{\boldsymbol{e}}\left[\mathbf{m g} / \mathbf{d m}^{\mathbf{3}}\right]$ & Mass adsorbed [g] & $\boldsymbol{q}_{\boldsymbol{e}}[\mathbf{m g} / \mathbf{g}]$ \\
\hline \multirow{3}{*}{3.50} & 5.00 & 2.60 & 0.90 & 0.180 \\
\cline { 2 - 5 } & 10.00 & 1.70 & 1.80 & 0.180 \\
\cline { 2 - 5 } & 15.00 & 1.20 & 2.30 & 0.153 \\
\cline { 2 - 5 } & 20.00 & 0.80 & 2.70 & 0.135 \\
\hline
\end{tabular}



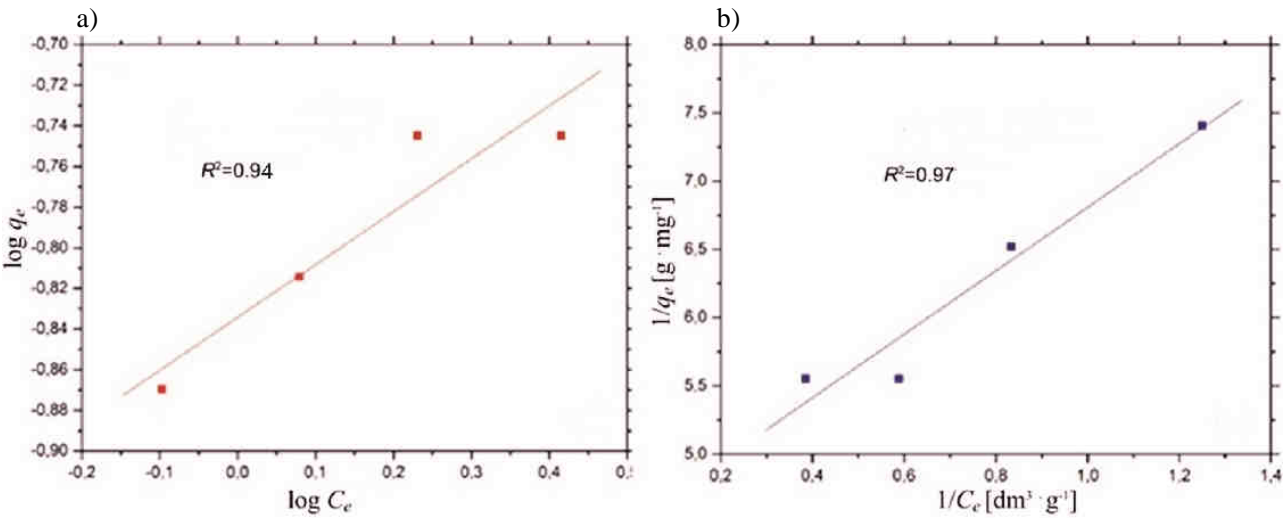

Fig. 5. Experimental data of fluoride sorption onto opoka sorbent fitted to linearized forms of: a) Freundlich isotherms and b) Langmuir isotherms

The following data were determined in accordance with ISO 8466-1: standard deviation $\left(\mathrm{mg} / \mathrm{dm}^{3} \mathrm{~F}^{-}\right) \pm 0.015$ of the measuring range $0.10-2.00 \mathrm{mg} / \mathrm{dm}^{3}$ and \pm 0.15 of the measuring range $\left(1.0-20.0 \mathrm{mg} / \mathrm{dm}^{3}\right)$; accuracy of a measurement value $\left(\mathrm{mg} / \mathrm{dm}^{3} \mathrm{~F}^{-}\right)$ $\max \pm 0.12$; sorbent opoka weight accuracy is $0.0001 \mathrm{~g}$.

Experimental data from tests of opoka sorption onto fluoride in rejected water were fitted to the linear forms of isotherms (equations (2) and (3)) which are graphically represented in Figure 5. The results indicate that in this case the Langmuir isotherm equation $\left(R^{2}=0.97\right)$ provided a better mathematical model or higher coefficient of determination to describe the adsorption equilibrium than Freundlich isotherm equation $\left(R^{2}=0.94\right)$. From the slope and intercept of the plot of each model we have determined the parameters of isotherms which are listed in Table 8.

Table 8 Equilibrium parameters of Freundlich isotherm and Langmuir isotherm determined from experimental data plotted in Figure 5 for fluoride sorption

\begin{tabular}{|c|c|c|c|}
\hline \multicolumn{2}{|c|}{ Freundlich isotherm } & \multicolumn{2}{c|}{ Langmuir isotherm } \\
\hline$K_{F}\left[\mathrm{dm}^{3 / 1 / n} \mathrm{mg}^{(1-1 / n)} / \mathrm{g}\right]$ & 0.4342 & $K_{L}\left[\mathrm{dm}^{3} / \mathrm{mg}\right]$ & 1.9283 \\
\hline $1 / n$ & 0.2602 & $q_{\max }[\mathrm{mg} / \mathrm{g}]$ & 0.2230 \\
\hline$R^{2}$ & 0.94 & $R^{2}$ & 0.97 \\
\hline & & $R_{L}$ & 0.1289 \\
\hline
\end{tabular}

The $R_{L}=0.1289$ value implies that sorption is favorable according to Langmuir isotherm conditions $\left(0<R_{L}<1\right)$. The maximum obtained sorption capacity of opoka sorbent was approximately $0.223 \mathrm{mg} / \mathrm{g}$ which is lower than the commercially produced aluminum based sorbents. Co-authors of this article were looking for cost efficient sorbent and opoka sorbent is appropriate due to it being a wasted material from excavation sites, while building construction sectors are only interested in big size fractions. Aluminum based exhausted sorbents are very expensive to reuse or to manage in the environment. Activated carbon sorbent was investigated in the water treatment plant of Kretinga town and it only provided negative results. Engineers responsible for drinking water treatment from a related Water Company were interested in the opoka sorbent usage and they 
continue research with opoka and similar sorbents. According to Environmental Law of Republic of Lithuania we proposed to incorporate exhausted opoka sorbent in cement production materials for local market use.

\section{SEM characterization of NF membranes}

After sampling surfaces of NF270 and NF90 were scanned by SEM. The images obtained $\times 5000$ are shown in Figure 6 .

From Figure 6, it can be obviously seen that NF70 has a smoother surface comparing to NF90 which contains many thin pricks with a complicated structure. In literature a previous study [43] with AFM technique has shown that NF270 represents lower roughness than NF90 which can explain the surface images obtained by the SEM technique. In general, the greater the degree of surface roughness is, the greater the surface area is available for foulants [45].
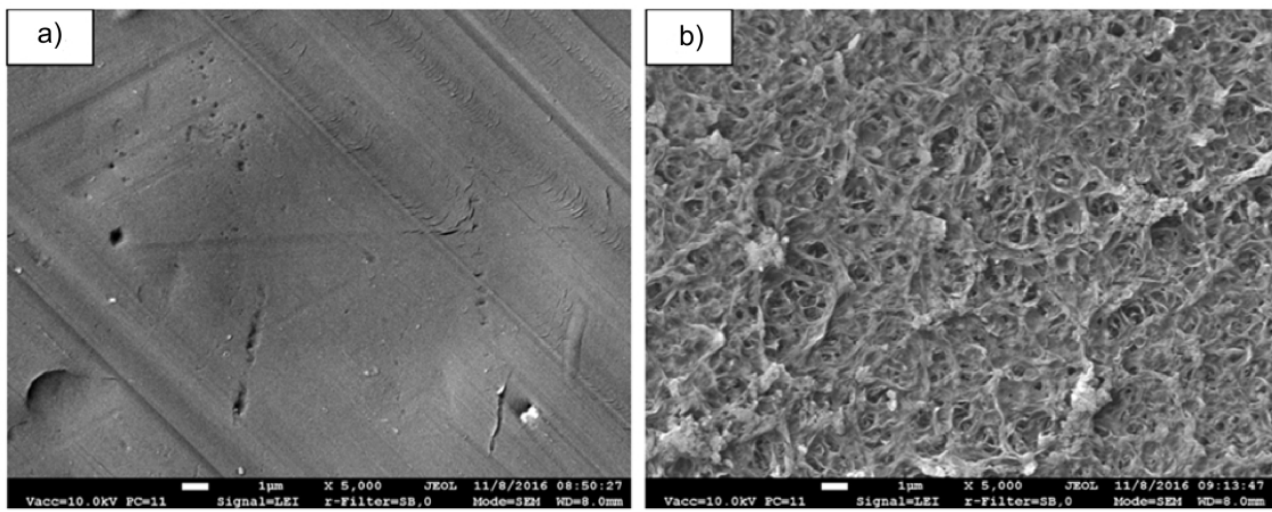

Fig. 6. SEM images of the surface of: a) NF270 and b) NF90 membranes $(\times 5000)$

\section{Membrane permeability}

Before studying the performance of membrane retention, we were firstly focused to get more information about membrane permeability to form an idea about the productivity flux for each studied NF membrane, which can help to make the choice of a membrane for a given application. The results of hydraulic permeability $\left(L_{p}\right)$ of pure water, permeability $\left(L_{p}{ }^{\prime}\right)$ with $\mathrm{NaF}$ solution $\left(10 \mathrm{mg} / \mathrm{dm}^{3}\right.$ of $\mathrm{F}^{-}$in solution $)$and critical pressure $\left(P_{c}\right)$ are provided in Table 9.

Table 9

Hydraulic permeability with pure water $\left(L_{p}\right)$ hydraulic permeability with saline water $\left(10 \mathrm{mg} / \mathrm{dm}^{3}\right.$ of $\mathrm{F}^{-}$solution $)$ $\left(L_{p}{ }^{\prime}\right)$, critical pressures $\left(P_{c}\right)$ for NF270 and NF90

\begin{tabular}{|c|c|c|c|}
\hline Membrane & $\boldsymbol{L}_{p}\left[\mathbf{d m}^{\mathbf{3}} /\left(\mathbf{h} \cdot \mathbf{m}^{2} \cdot \mathbf{M P a}\right)\right]( \pm \mathbf{0 . 7})$ & $\begin{array}{c}\boldsymbol{L}_{p} \boldsymbol{}\left[\mathbf{d m}^{\mathbf{3}} /\left(\mathbf{h} \cdot \mathbf{m}^{2} \cdot \mathbf{M P a}\right)\right] \\
(\mathbf{0 . 3})\end{array}$ & $\boldsymbol{P}_{c}[\mathbf{M P a}]( \pm \mathbf{0 . 0 0 1})$ \\
\hline NF270 & 54.8 & 45.7 & 0.030 \\
\hline NF90 & 44.4 & 40.6 & 0.112 \\
\hline
\end{tabular}

The hydraulic permeability values of 54.8 and $44.4 \mathrm{dm}^{3} /\left(\mathrm{h} \cdot \mathrm{m}^{2} \cdot \mathrm{MPa}\right)$ were recorded respectively for NF270 and NF90 which means that NF270 was more permeable. 
The difference in permeability was directly related to their different pore diameter $[44,45]$. From the evolution of permeate flow rate of the saline solution basing on Eq. (5) as a function of pressure, it is possible to estimate the critical pressure beyond the starting filtration pressure to the flow of solvent $J_{v}=0$. For the studied NF membranes (NF270 and NF90), the critical pressure is under 0.2 MPa. The accumulation of $\mathrm{NaF}$ on the membrane surface is usually limited by the high flow rate and the imposed low conversion rate [17].

\section{Fluoride rejection in single salt solution}

Fluoride retention has been studied using $\mathrm{NaF}$ solutions at different concentrations of fluoride $\left(5\right.$ and $10 \mathrm{mg} / \mathrm{dm}^{3}$ ). Usually, to compare the selectivity of different NF membranes for fluoride removal, the graph of the observed retention $\left(R_{o b s}\right)$ as function of the applied pressure $(\Delta P)$ is used (see Fig. 7). For the two studied NF membranes the data obtained at $\Delta P=0.4,0.8$ and $1.2 \mathrm{MPa}$ are reported in Table 10 .
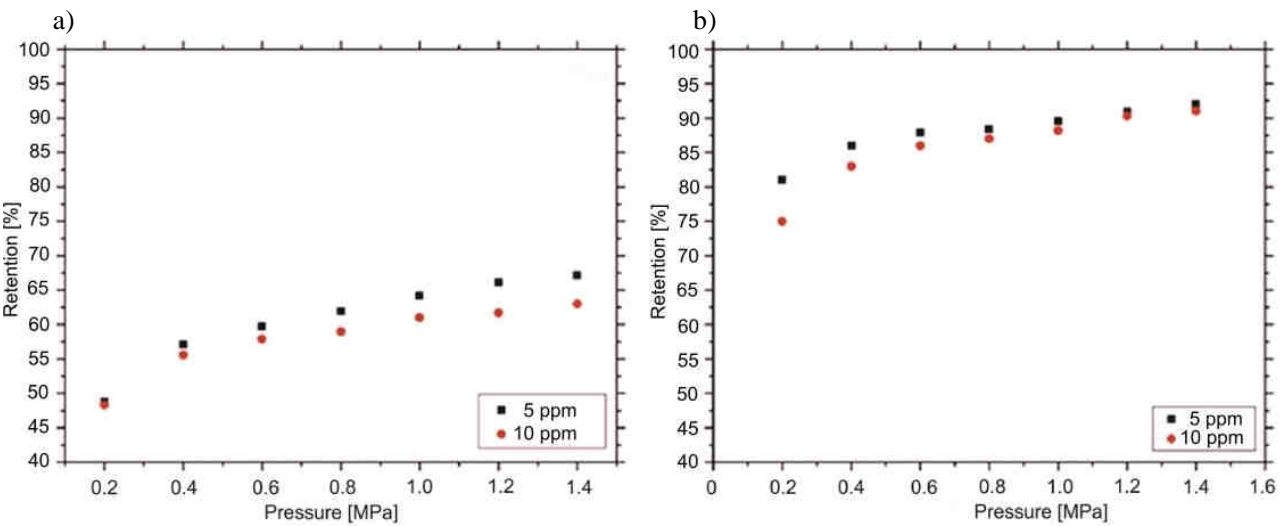

Fig. 7. Fluoride retention as functions of the transmembrane pressure at 5 and $10 \mathrm{mg} / \mathrm{dm}^{3}$ for: a) NF270 and b) NF90 (pH = 6.7; $\left.T=24{ }^{\circ} \mathrm{C} ; Y=15 \%\right)$

Fluoride retention at three pressures, and two different concentrations for NF270 and NF90 membranes

\begin{tabular}{|c|c|c|c|c|c|c|}
\hline \multicolumn{9}{|c|}{$\boldsymbol{R}_{\text {obs }}[\%]$} \\
\hline$\left[\mathbf{F}^{-}\right]$ & \multicolumn{3}{|c|}{$\left.\mathbf{5} \mathbf{m g} / \mathbf{d m}^{3}\right]$} & \multicolumn{3}{c|}{$\mathbf{1 0}\left[\mathbf{m g} / \mathbf{d m}^{3}\right]$} \\
\hline Pressure [MPa] & 0.4 & 0.8 & 1.2 & 0.4 & 0.8 & 1.2 \\
\hline NF270 & 5.7 & 6.2 & 6.6 & 5.6 & 5.9 & 6.2 \\
\hline NF90 & 8.6 & 8.8 & 9.1 & 8.3 & 8.7 & 9.0 \\
\hline
\end{tabular}

According to Figure 7, NF90 gives better retention rate than NF270 for $5 \mathrm{mg} / \mathrm{dm}^{3}$ and $10 \mathrm{mg} / \mathrm{dm}^{3}$ of fluoride. In case of NF90, fluoride retention can reach $92 \%$ at $5 \mathrm{mg} / \mathrm{dm}^{3}$ while in case of NF270 fluoride retention reaches $67 \%$. The retention amount in NF membranes is highly dependent on the pores' size. The influence of the concentration on fluoride retention reveals a fairly wide gap at low pressure (between 0.2 and $0.4 \mathrm{MPa}$ ) for NF90 between both retentions of $\mathrm{F}^{-}$, while in case of NF270, this difference is noticed at pressure higher than 0.6 MPa. This influence of the concentration on fluoride retention can be explained by the phenomenon of concentration polarization [46]. Generally, NF 
membranes allow us to have partial and selective demineralization in addition to an important production flow, which makes the nanofiltration technique competitive to reverse osmosis [47].

\section{Conclusions}

- The experiments have shown good performance of opoka sorbent for fluoride removal from membrane reject water with an efficiency higher than $77 \%$.

- X-ray characterization showed that opoka stone is a material rich in calcium, which can be the responsible element of fluoride sorption.

- The application of results on equilibrium isotherms revealed that Langmuir isotherm provide better linearity with a coefficient of determination $R^{2}=0.97$, while Freundlich isotherm has provided a coefficient of determination $R^{2}=0.94$. The parameters of isotherms determined allowed us to give an idea about the maximum sorption capacity of opoka sorbent $\left(q_{\max }=0.223 \mathrm{mg} / \mathrm{g}\right)$.

- In case of membrane process, it has been shown that NF90 membrane can retain $90 \%$ of fluoride ions, while NF270 can retain $66 \%$.

- The results of permeability reveal to us that NF270 membrane is more productive when comparing to NF90 membrane.

- The combination of nanofiltration technique with sorption process can lead us to an optimal treatment of fluoride from the groundwater of Kretinga town (Lithuania) with lower cost than when using RO and without harming the environment.

\section{Acknowledgments}

Co-authors would like to express special gratitude for technical assistance to the Scientific Institute of Thermal Insulation from Vilnius Gediminas Technical University, Lithuania.

\section{References}

[1] Fawell J, Bailey K, Chilton J, Dahi E, Fewtrell L, Magara Y. Fluoride in Drinking-water. World Health Organization; 2006. https://www.who.int/water_sanitation_health/publications/fluoride_drinking water_full.pdf.

[2] Mohapatra M, Anand S, Mishra BK, Giles Dion E, Singh P. Review of fluoride removal from drinking water. J Environ Manage. 2009;91:67-77. DOI: 10.1016/j.jenvman.2009.08.015.

[3] Azbar N, Turkman A. Defluoridation in drinking waters. Water Sci Technol. 2000;42:403-407. DOI: 10.2166/wst.2000.0346.

[4] Ayoob S, Gupta AK. Fluoride in drinking water: a review on the status and stress effects. Crit Rev Environ Sci Technol. 2006;36:433-487. DOI: 10.1080/10643380600678112.

[5] Vithanage M, Bhattacharya P. Fluoride in the environment: sources, distribution and defluoridation. Environ Chem Lett. 2015;13:131-147. DOI: 10.1007/s10311-015-0496-4.

[6] Wang W, Li R, Tan J, Luo K, Yang L, Li H, et al. Adsorption and leaching of fluoride in soils of China. Fluoride. 2002;35(2):122-129. ISSN: 0015-4725.

[7] Agarwal M, Rai K, Shrivastav R, Dass S. Defluoridation of water using amended clay. J Cleaner Products. 2003;11:439-444. DOI: 10.1016/j.arabjc.2014.06.005.

[8] Chaudhary V, Satheeshkumar S. Assessment of groundwater quality for drinking and irrigation purposes in arid areas of Rajasthan, India. Appl Water Sci. 2018;8:218. DOI: 10.1007/s13201-018-0865-9.

[9] Petersen PE, Aleksejuniene J, Christensen LB, Eriksen HM, Kalo I. Oral health behavior and attitudes of adults in Lithuania. Acta Odontol Scand. 2000;58:243-248. DOI: 10.1080/00016350050217073. 
[10] Menkouchi Sahli MA, Annouar S, Tahaikt M, Mountadar M, Soufiane A, Elmidaoui A. Fluoride removal for underground brackish water by adsorption on the natural chitosan and by electrodialysis. Desalination. 2007;212:37-45. DOI: 10.1016/j.desal.2006.09.018.

[11] Msonda KWM, Masamba WRL, Fabiano E. A study of fluoride groundwater occurrence in Nathenje, Lilongwe, Malawi. Phys Chem Earth. 2007;32:1178-1184. DOI: 10.1016/j.pce.2007.07.050.

[12] Rao N. Fluoride in groundwater, Varaha River Basin, Visakhapatnam District, Andhra Pradesh, India. Environ Monit Assess. 2009;152:47-60. DOI: 10.1007/s10661-008-0295-5.

[13] Wang GQ, Huang YZ, Xiao BY, Qian XC, Yao H, Hu Y, et al. Toxicity from water containing arsenic and fluoride in Xinjiang. Fluoride. 1997;30:81-84. ISSN: 0015-4725.

[14] Neuhold JM, Sigler WF. Effects of sodium fluoride on carp and rainbow trout. Trans Am Fish Soc. 1960;89:358-370. DOI: 10.1577/1548-8659(1960)89[358:EOSFOC]2.0.CO;2.

[15] Colombani N, Kebede S, Salemi E, Mastrocicco M. Recognition of the anthropogenic contribution to the input of fluoride in urban recharge. Environ Earth Sci. 2018;77:390-399. DOI: 10.1016/j.gexplo.2018.04.008.

[16] Peckham S, Awofeso N. Water Fluoridation: A critical review of the physiological effects of ingested fluoride as a public health intervention. Sci World J. 2014;9:1-10. DOI: 10.1155/2014/293019.

[17] Pontie M, Diawara C, Lhassani A, Dach H, Rumeau M, Buisson H, et al. Chapter 2 water defluoridation processes: A review application: nanofiltration (NF) for future large-scale pilot plants. Adv Fluorine Sci. 2006;2:49-80. DOI: 10.1080/19443994.2012.704715.

[18] Wasana HM, Aluthpatabendi D, Kularatne WM, Wijekoon P, Weerasooriya R, Bandara J. Drinking water quality and chronic kidney disease of unknown etiology $(\mathrm{CKDu})$ : synergic effects of fluoride, cadmium and hardness of water. Environ Geochem Health. 2016;38(1):157-168. DOI: 10.1007/s10653-015-9699-7.

[19] Saucedo-Delgado BG, De Haro-Del Rio DA, González-Rodríguez LM, Reynel-Ávila HE, Mendoza-Castillo DI, Bonilla-Petriciolet A, et al. Fluoride adsorption from aqueous solution using a protonated clinoptilolite and its modeling with artificial neural network-based equations. J Fluorine Chem. 2017;204:98-106. DOI: 10.1016/j.jfluchem.2017.11.002.

[20] Silveira C, Shimabuku QL, Fernandes Silva M, Bergamasco R. Iron-oxide nanoparticles by the green synthesis method using Moringa oleifera leaf extract for fluoride removal. Environ Technol. 2018;39(22):2926-2936. DOI: 10.1080/09593330.2017.1369582.

[21] Mullick A, Neogi S. Ultasound assisted synthesis of Mg-Mn-Zr impregnated activated carbon for effective fluoride adsorption from water. Ultrasonics - Sonochemistry. 2019;50:126-137. DOI: 10.1016/j.ultsonch.2018.09.010.

[22] Xu L, Gao X, Li Z, Gao C. Removal of fluoride by nature diatomite from high-fluorine water: an appropriate pretreatment for nanofiltration process. Desalination. 2015;369:97-104. DOI: 10.1016/j.desal.2015.04.033.

[23] Dolar D, Košutić K, Vučić B. RO/NF treatment of wastewater from fertilizer factory - removal of fluoride and phosphate. Desalination. 2011;265:237-241. DOI: 10.1016/j.desal.2010.07.057.

[24] Jadhav SV, Gadipelly CR, Marathe KV, Rathod VK. Treatment of fluoride concentrates from membrane unit using salt solutions. J Water Process Eng. 2014;2:31-36. DOI: 10.1016/j.jwpe.2014.04.00.

[25] Reardon E, Wang Y. A limestone reactor for fluoride removal from wastewaters. Environ Sci Technol. 2000;34:3247-3253. DOI: 10.1021/es990542k.

[26] Mulugeta E, Zewge F, Chandravanshi BS. Development of a household water defluoridation process using aluminium hydroxide based adsorbent. Water Environ Res. 2015;87(6):524-532. DOI: 10.2175/106143014X13975035525627.

[27] Pontie M, Dach H, Lhassani A, Diawara CK. Water defluoridation using nanofiltration vs. reverse osmosis: the first world unit, Thiadiaye (Senegal). Desalin Water Treat. 2012;51:164-168. DOI: 1080/19443994.2012.704715.

[28] Chakrabortty S, Roy M, Pal P. Removal of fluoride from contaminated groundwater by cross flow nanofiltration: transport modeling and economic evaluation. Desalination. 2013;313:115-124. DOI: 10.1016/j.desal.2012.12.021.

[29] Shen J, Richards BS, Schäfer AI. Renewable energy powered membrane technology: case study of St. Dorcas Borehole in Tanzania demonstrating fluoride femoval via nanofiltration/reverse osmosis. Sep Purif Technol. 2016;170:445-452. DOI: 10.1016/j.seppur.2016.06.042.

[30] Elazhar F, Tahaikt M, Zouahri A, Taky M, Hafsi M, Elmidaoui A. Defluoridation of Moroccan groundwater by nanofiltration and electrodialysis: performances and cost comparison. World Appl Sci J. 2013;22(6):844-850. DOI: 10.5829/idosi.wasj.2013.22.06.268.

[31] Smittakorn S, Jirawongboonrod N, Mongkolnchai-arunya S, Durnford D. Homemade bone charcoal adsorbent for defluoridation of groundwater in Thailand. J Water Health. 2010;8(4):826-836. DOI: 10.2166/wh.2010.131. 
[32] Ramdani A, Taleb S, Benghalem A, Ghaffour N. Removal of excess fluoride ions from Saharan brackish water by adsorption on natural materials. Desalination. 2010;250:408-413. DOI: 10.1016/j.desal.2009.09.066\}.

[33] Oladoja NA, Helmreich B, Bello HA. Towards the development of a reactive filter from green resource for groundwater defluoridation. Chem Eng J. 2016;301:166-177. DOI: 10.1016/j.cej.2016.04.150.

[34] Tang Y, Guan X, Wang J, Gao N, McPhail MR, Chusuei CC. Fluoride adsorption onto granular ferric hydroxide: Effects of ionic strength, $\mathrm{pH}$, surface loading, and major co-existing anions. J Hazard Mater. 2009;171:774-779. DOI: 10.1016/j.jhazmat.2009.06.079.

[35] Lithuanian hygiene norm HN 24: 2003. Safety and quality requirements for drinking water. 2003. https://e-seimas.lrs.lt/portal/legalAct/lt/TAD/TAIS.216309.

[36] Brogowski Z, Renman G. Characterization of Opoka as a basis for its use in wastewater treatment. Polish J Environ Stud. 2004;13(1):15-20. WOS: 000189090000002. http://www.pjoes.com/Characterization-ofOpoka-as-a-Basis-for-its-Use-r-nin-Wastewater-Treatment-,87622,0,2.html.

[37] Cucarella V, Zaleski T, Mazurek R. Phosphorus sorption capacity of different types of opoka. Ann Warsaw Agricult Univ - SGGW, Land Reclam. 2007;38:11-18. https://www.researchgate.net/publication/310487634.

[38] Johansson L, Gustafsson JP. Phosphate removal using blast furnace slags and opoka-mechanisms. Wat Res. 2000;34(1):259-265. DOI: 10.1016/S0043-1354(99)00135-9.

[39] Buzaeva MV, Pis'menko VT, Klimov ES. Decomposition of coolants using modified opoka. Chem Technol Fuels Oils. 2010;46(3):160-163. DOI: 10.1007/s10553-010-0203-X.

[40] Wdowin M, Franus W, Panek R. Preliminary results of usage possibilities of carbonate and zeolitic sorbents in $\mathrm{CO}_{2}$ capture. Fresen Environ Bull. 2012;21(12):3726-3734. https://www.prt-parlar.de/download_feb_2012/.

[41] LST EN 933-2:2001. Tests for Geometrical Properties of Aggregates. Part 2: Determination of Particle Size Distribution - Test Sieves, Nominal Size of Apertures. Lithuanian Standards Board. http://lsd.lt/index.php?1416447412.

[42] Tomczak E, Blus M. Characteristics of polymeric ultrafiltration membranes produced with the use of graphene oxide. Ecol Chem Eng S. 2018;25(3):419-429, DOI: 10.1515/eces-2018-0029.

[43] Chung HK, Kim WH, Park J, Cho J, Jeong TY, Park PK. Application of Langmuir and Freundlich isotherms to predict adsorbate removal efficiency or required amount of adsorbent. J Ind Eng Chem. 2015;28:241-246. DOI: 10.1016/j.jiec.2015.02.021.

[44] Pontie M, Dach H, Leparc J, Hafsi M, Lhassani A. Novel approach combining physico-chemical characterizations and mass transfer modelling of nanofiltration and low pressure reverse osmosis membranes for brackish water desalination intensification. Desalination. 2008;221:174-191. DOI: 10.1016/j.desal.2007.01.075.

[45] Johnson D, Hilal N. Characterisation and quantification of membrane surface properties using atomic force microscopy: A comprehensive review. Desalination. 2015;356:149-164. DOI: 10.1016/j.desal.2014.08.019.

[46] Kelewou H, Lhassani A, Merzouki M, Drogui P, Sellamuthu B. Salts retention by nanofiltration membranes: Physicochemical and hydrodynamic approaches and modeling. Desalination. 2011;277:106-112. DOI: 10.1016/j.desal.2011.04.010.

[47] Lhassani A, Rumeau M, Benjelloun D, Pontie M. Selective demineralization of water by NF, application to the defluorination of brackish water. Water Res. 2001;35:3260-3264. DOI: 10.1016/S0043-1354(01)00020-3. 